\title{
Study on the Physical Quality of Complete Rabbit Feed Pellets Using Different Forage Protein Sources
}

\author{
T. A. Y. Foenay, and T. N. I. Koni \\ Kupang State Agricultural Polytechnic \\ Jl. Prof. Dr. Herman Yohanis, Lasiana, Kupang 85011, NTT, Indonesia \\ Corresponding author: anggarini.foenay@gmail.com
}

\begin{abstract}
This study evaluated the physical quality of complete rabbit feed containing different legumes. The study design was an experimental method using a Completely Randomized Design with four treatments and five replications. The treatments were as follows: P1 = complete feed without legume; P2 = complete feed with $10 \%$ moringa leaves meal; P3 = complete feed with $10 \%$ Leucaena leaves meal; P4 $=$ complete feed with $10 \%$ turi leaves meal. Parameters measured were hardness, durability, density and specific gravity of rabbit pellet complete feed. Data analysis uses analysis of variance and if there is a treatment with a significant effect, then it is continued with Duncan's multiple distance test. The results showed that legumes had no significant effect on impact resistance, friction resistance, pile density and specific gravity of the rabbit pellets produced. It was concluded that the use of legumes, namely Moringa, lamtoro and turi did not reduce the physical quality of the pellets.
\end{abstract}

Keywords: moringa, Leucaena, turi, physical quality, rabbit pellet

\section{INTRODUCTION}

Feed is one factor that affects the growth of livestock, including rabbits, both ornamental rabbits and broiler rabbits. Preparation of animal feed requires protein source feed such as soybean meal, which tends to have a fairly high price. Rabbits are pseudo ruminants that usually consume feed from forage sources. Some forage legumes have a fairly high protein content such as moringa, lamtoro and turi. This forage is available in NTT and is usually used as fodder for ruminants. The use of forage protein sources can meet the needs of rabbits for crude protein and also crude fiber. The manufacture of complete feed that already contains forage so there is no need to provide fresh forage for rabbits and also reduces the cost of purchasing protein source feed ingredients. The growth and reproduction of rabbits depend on the type, amount and quality of feed. McNitt, et al. (2011) stated that rabbit feed can be sourced from forage and concentrates. Marhaeniyanto et al. (2015) stated that forages such as field grass, vegetable waste, are a source of fiber for rabbits, while protein is usually sourced from concentrates. The production of rabbit concentrate as a protein source is usually used as a fish meal or soybean meal which has a fairly high price, so to save on feed costs it is necessary to look for forage feed ingredients high in protein content. Rabbits consume forage, therefore to reduce feed costs, the use of forage protein sources which usually come from legumes, can be an alternative source of protein such as lamtoro, turi and moringa.

Moringa (Moringa oleifera) is one of the shrubs that can be used as feed ingredients and is quite widely available in Indonesia (Daryatmo and Hakim, 2017). Moringa is a type of plant that contains nutrients, namely crude protein 25.55 $29.61 \%$, crude fiber $8.9-10.82 \%$ and crude fat $5.79 \%$ (Marhaeniyanto et al., 2015; Sjofjan, 2008) ); metabolic energy $1318.20 \mathrm{kcal} / \mathrm{kg}$ (Sjofjan, 2008). Moringa is a plant that can be used for malnourished children (Dewanti et al., 2016). Furthermore, it was explained that the protein, carbohydrates, and fat levels in Moringa plants in NTT were $27.02 \%, 27.33 \%$, and $1.97 \%$, respectively. Lamtoro (Leucaena leucocephala) is a type of legume widely used for animal feed. The chemical composition of lamtoro leaves, namely dry matter $97.8923 \%$; crude protein $23.83 \%$, extract without nitrogen (BETN) $31.05 \%$, crude fiber $23.59 \%$, fat $11.69 \%$ and ash $7.74 \%$ (Kastalani, 2015). Giving lamtoro leaves can increase carcass weight in rabbits, giving it up to $60 \%$ (Kastalani, 2015), but in the study of Yurmiaty and Suradi (2007), they give lamtoro leaves $20 \%$ can cause book loss. It is recommended to use up to $10 \%$ in rabbit feed. . Turi (Sesbania grandiflora) is a type of treeshaped legume. Animal feed using turi forage is very beneficial because it is a source of mineral protein and feed reserves. One type of legume tree that is very good to be given to ruminants is turi leaf where the protein content is $18.8-31.7 \%$, 
crude fat 1.9- 4.80\% (Utami et al., 2012) and crude fiber content. 15.4-17.8\% (Gohl, 1981). Complete feed for rabbits is made in pellets so that it is more efficient. McNitt et al. (2011) stated that feed processing such as pellets has several advantages: improving quality, eliminating antinutrients, increasing palatability, and facilitating feed handling. It was further stated that rabbits preferred feed in pellets rather than flour. Abdollahi et al. (2013) stated that pellets can increase consumption and performance in livestock. Retnani et al. (2011) stated that the quality of pellets is highly dependent on the ingredients that make up the feed itself. Therefore, this study was conducted to examine the physical quality of rabbit feed pellets using different forage protein sources.

\section{MATERIALS AND METHODS}

The pellet production was conducted at the Mini Animal Feed Factory and the Nutrition and Animal Feed Laboratory, Kupang State Agricultural Polytechnic.

\section{Research Material}

The materials used in the study were Moringa leaf flour, lamtoro leaves, turi leaves, soybean meal, corn, pollard. The tools used include scales, feed milling machines, pellet molding machines, and Durability Testers.

\section{Research Procedure}

The procedures carried out in this study are:

1. Feed formulation. Feed formulated for growing rabbits has a requirement of $14-16 \%$ crude protein, $12-14 \%$ crude fiber, metabolic energy $2380-2400 \mathrm{kcal} / \mathrm{kg}, 3-5 \%$ fat, Ca $0.4-0.5 \%$ and $\mathrm{P} 0.3 \%$ as recommended (McNitt et al., 2011).

2. Preparation of forage flour and forages such as moringa, lamtoro and turi are then separated between leaves and twigs. The forage is dried for 2 days in the sun until it is completely dry.

3. Milling. After drying, it is floured using a disk mill with a $1.5 \mathrm{~mm}$ sieve.

4. Weighing, the feed ingredients were weighed according to the formulation in each treatment.

5. Mixing. The feed ingredients are mixed manually until homogeneous.

6 . Pellet molding. The homogeneously mixed feed is sprinkled with a little water and then put into the pellet machine for printing.

7. Drying. The pellets that have been printed are then dried in the sun to dry for 2 days.

8. The dried pellets were then tested, namely physical and chemical quality tests, from 100 grams of pellet samples from each experimental unit sent to the laboratory for proximate and antinutrient analysis.

\section{Research design}

Rabbit feed is made using several forage protein sources molded in pellet form. The design in this study was a completely randomized design (CRD) with 4 treatments and 5 replications. The treatments given are:

P1 = complete feed for rabbits without the use of forage

P2 = complete feed using $10 \%$ Moringa flour

P3 = complete feed using 10\% lamtoro flour

P4 = complete feed using $10 \%$ turi flour

Table 1. Complete feed formulation using different forage protein sources

\begin{tabular}{lccccc}
\hline \multirow{2}{*}{ Feed Ingredients } & \multirow{2}{*}{ Unit } & \multicolumn{4}{c}{ Treatment } \\
\cline { 3 - 6 } & & $\mathrm{P} 0$ & $\mathrm{P} 1$ & $\mathrm{P} 2$ & $\mathrm{P} 3$ \\
\hline Yellow Corn & $\mathrm{kg}$ & 3,70 & 3,70 & 3,70 & 3,70 \\
Fine bran & $\mathrm{kg}$ & 4,00 & 4,00 & 4,00 & 4,00 \\
Vegetable oil & $\mathrm{kg}$ & 0,20 & 0,20 & 0,20 & 0,20 \\
Soybean meal & $\mathrm{kg}$ & 1,20 & 0,20 & 0,20 & 0,20 \\
MBM & $\mathrm{kg}$ & 0,80 & 0,80 & 0,80 & 0,80 \\
Dicalcium phosphate & $\mathrm{kg}$ & 0,05 & 0,05 & 0,05 & 0,05 \\
Limestone & $\mathrm{kg}$ & 0,00 & 0,00 & 0,00 & 0,00 \\
Topmix & $\mathrm{kg}$ & 0,05 & 0,05 & 0,05 & 0,05 \\
Moringa & $\mathrm{kg}$ & 0,00 & 1,00 & 0,00 & 0,00 \\
Turi & $\mathrm{kg}$ & 0,00 & 0,00 & 1,00 & 0,00 \\
Lamtoro & $\mathrm{kg}$ & 0,00 & 0,00 & 0,00 & 1,00 \\
\hline Total & \multicolumn{5}{c}{10,00} \\
\hline Information P0: complete feed for rabbits without the use of forage, P1: complete feed using Moringa, P2: \\
\multicolumn{7}{c}{ complete feed using lamtoro, P3: complete feed using turi. }
\end{tabular}




\section{Research Parameter}

The parameters measured were the physical properties of the pellet, namely friction resistance, impact resistance and specific gravity. Friction resistance was measured by the pfost tumbling method in accordance with the opinion of Retnani et al. (2011), namely by means of a 500 -gram sample inserted into a rotating drum for 10 minutes at a speed of $50 \mathrm{rpm}$. The remaining pellet is then filtered and weighed to get its weight. The percentage of the number of pellets that are still intact is the value of pellet durability. Pellet durability or pellet resistance to friction can be done using the pfost tumbling method or a pellet durability tester.

Pellet durability formula $=\frac{\text { Weight after tumbling }}{\text { Weight before tumbling }} \mathrm{X} 100$

The pellet resistance test against impact was carried out using the Shatter Test method based on Retnani et al. (2011), where the pellet sample put in the box was dropped from a height of 1 meter, namely onto an iron plate. The percentage of impact resistance is calculated by comparing the weight of the whole pellet after being dropped with the weight of the whole pellet before it is dropped.

\section{Data Analysis}

Data on the effect of forage protein sources on the physical quality of pellets was processed by analysis of variance using a completely randomized design with a unidirectional pattern and if there was a significant effect, continued with Duncan's new Multiple Range Test (DMRT) (Gasperz, 2006).

\section{RESULT AND DISCUSSION}

\section{Impact Resistance}

Impact resistance measurements was carried out to determine whether the pellets produced were resistant to impact, falling or being crushed freely during storage or transportation (Krisnan and Ginting, 2009). Impact resistance of complete rabbit feed pellets using forage protein sources is shown in Table 2 .

The Anova test showed that the use of different protein sources had no significant effect (P>0.05) on the impact resistance of the pellets. These results indicate that pellets prepared using different forage protein sources produce pellets of the same quality. Possibly this is because the forage used has the same particle size, which is milled with a sieve size of $3 \mathrm{~mm}$. Chewning et al. (2012) stated that the smaller particle size of feed ingredients resulted in good pellet quality. Saenab et al. (2010) stated that the particle size of the raw materials that make up the pellets will affect the pellets' strength. Compared with commercial feeds with an impact resistance of $99.8 \%$ (Retnani et al., 2010), the results of this study have good impact resistance, namely 98.80 to 99.40 , which indicates that the use of different forage protein sources does not reduce the impact resistance of the resulting pellet.

Table 2. Average impact resistance, friction resistance, pile compaction density and specific gravity of complete feed pellets for rabbits with different forage protein sources

\begin{tabular}{cllll}
\hline Treatment & $\begin{array}{c}\text { Impact } \\
\text { Resistance }(\%)\end{array}$ & $\begin{array}{c}\text { Friction } \\
\text { Resistance }(\%)\end{array}$ & $\begin{array}{c}\text { Heap compaction } \\
\text { density }\left(\mathrm{g} / \mathrm{cm}^{3}\right)\end{array}$ & $\begin{array}{c}\text { Specific gravity } \\
\left(\mathrm{g} / \mathrm{cm}^{3}\right)\end{array}$ \\
\hline P0 & $99,40 \pm 0,55$ & $92,96 \pm 3,56$ & $0,57 \pm 0,02$ & $1,34 \pm 0,09$ \\
P1 & $99,40 \pm 0,55$ & $90,72 \pm 0,42$ & $0,56 \pm 0,04$ & $1,40 \pm 0,16$ \\
P2 & $99,40 \pm 0,55$ & $91,68 \pm 0,50$ & $0,55 \pm 0,05$ & $1,47 \pm 0,22$ \\
P3 & $98,80 \pm 0,45$ & $92,12 \pm 1,87$ & $0,57 \pm 0,12$ & $1,34 \pm 0,09$ \\
\hline P value & 0,221 & 0,307 & 0,817 & 0,454 \\
\hline
\end{tabular}

Note: $\mathrm{P} 0=$ complete feed for rabbits without the use of forage; $\mathrm{P} 1=$ complete feed using $10 \%$ Moringa flour; $\mathrm{P} 2=$ complete feed using $10 \%$ lamtoro flour; P3 = complete feed using $10 \%$ turi flour

\section{Friction Resistance}

The friction resistance value is known to determine the quality of the resulting pellet sturdiness and evaluate the feed material's characteristics during the pellet molding process (Akbar et al., 2017). A good pellet is a pellet with a high pellet durability index so as not to be physically damaged, remains compact, sturdy and not easily damaged during the pellet handling and transportation process (Jaelani et al., 2016). Friction resistance of complete rabbit feed pellets using forage protein sources is shown in Table 2. The analysis of variance showed that the treatments were not significantly different $(\mathrm{P}>0.05)$ on friction resistance or durability. The durability value of 90.72 to $92.96 \%$ means that the treatment using different forage protein sources having a durability value of more than $90 \%$ is still 
considered good. Akhadiarto (2010) stated that pellets are considered good if the durability value is greater than 90\%; Dozier et al. (2010) stated that the minimum standard for Pellet Durability Index (PDI) specifications is $80 \%$.

\section{Stack Density}

Factors that also affect the density of the feed pile, namely the particle size or the level of fineness of the feed, the larger the feed particle size, the lower the pile density level (Jaelani et al., 2016). Stack density can determine the density of the pellet feed produced and is one of the factors in the automatic dosing of pellet feed (Akbar et al., 2017). The pile density of complete rabbit feed pellets using forage protein sources is shown in Table 2. The use of forage protein sources in rabbit pellets had no significant effect $(\mathrm{P}>0.05)$ on the value of stack density. The average density of commercial feed pellets in the form of pellets according to Retnani et al. (2011) is $0.7 \mathrm{~g} \mathrm{~mL}-1$. The results obtained in this study ranged from $0.55-0.57 \mathrm{~g} \mathrm{~mL}-1$. The smaller value of the stacking density in this study indicates that the same pellet feed weight requires more space or volume. These results can affect the size of the packaging and the process of transporting pellet feed.

\section{Specific Gravity}

Density is the ratio of the mass of the material to its volume. Specific gravity plays an important role in the processing, handling and storage (Nurhayatin and Puspitasari, 2017). Akbar et al. (2017) stated that specific gravity is the determinant of the size of the pellet feed package. The analysis of variance of specific gravity showed that different forage protein sources had no significant effect $(\mathrm{P}>0.05)$ on specific gravity. The specific gravity in this study ranged from 1.34 to 1.47 .

\section{Water Content}

The water content of the feed will affect the length of storage of the feed ingredients. The amount of water content in a feed ingredient can be known when the feed material is heated at a temperature of $105^{\circ} \mathrm{C}$. Dry matter is obtained by calculating the difference between $100 \%$ and the percentage of moisture content of a feed material heated to a fixed size (Anggorodi, 1994). Halid (1994) explains that water content is the amount of water content in a material based on dry weight, which is influenced by the type of material, temperature, and humidity. Table 3 presents the average water content of each treatment.

Table 3. Average water content, crude fat, and crude fiber complete feed for rabbits with different forage protein sources

\begin{tabular}{cccc}
\hline Treatment & Water Content $(\%)$ & Crude Fat $(\%)$ & Coarse Fiber $(\%)$ \\
\hline P0 & $4,280 \pm 0,08^{\mathrm{b}}$ & $6,84 \pm 0,45^{\mathrm{a}}$ & $12,20 \pm 0,03^{\mathrm{c}}$ \\
P1 & $5,21 \pm 0,22^{\mathrm{a}}$ & $3,77 \pm 2,91^{\mathrm{b}}$ & $13,99 \pm 0,16^{\mathrm{b}}$ \\
P2 & $4,32 \pm 0,47^{\mathrm{b}}$ & $8,63 \pm 0,05^{\mathrm{a}}$ & $14,80 \pm 0,73^{\mathrm{a}}$ \\
P3 & $4,99 \pm 0,11^{\mathrm{a}}$ & $8,4 \pm 0,83^{\mathrm{a}}$ & $14,10 \pm 0,10^{\mathrm{ab}}$ \\
Pvalue & 0,005 & 0,017 & 0,000 \\
\hline
\end{tabular}

Note: $\mathrm{P} 0=$ complete feed for rabbits without the use of forage; $\mathrm{P} 1=$ complete feed using $10 \%$ Moringa flour; $\mathrm{P} 2$ $=$ complete feed using $10 \%$ lamtoro flour; $\mathrm{P} 3=$ complete feed using $10 \%$ turi flour

The results of the analysis of variance showed that the use of different forage protein sources in this study had a significant $(\mathrm{P}<0.05)$ effect on water content. This difference in water content is influenced by differences in the materials used, the type of ingredients that make up the complete feed affect the water content of the resulting feed (Halid, 1994). Based on Duncan's multiple spacing, the treatment without forage was not different from the treatment using lamtoro leaves (P2), and significantly different $(\mathrm{P}<0.05)$ with the treatment using Moringa $(\mathrm{P} 1)$ and Turi (P3). The water content in this study was 4.28 to $5.21 \%$. The results of this study are in accordance with the Indonesian National Standard that the maximum water content of the pelleted feed is $14 \%$ (SNI, 2020). The water content in this study was lower than the results of Sholiha's (2011) study which reported that the water content of the addition of Indigofera sp legumes ranged from $7-11 \%$.

\section{Crude Fat}

The value of the fat content of the feed ingredients is known by drying the feed ingredients until they are free of water and filtered in ethyl ether after dissolving in ethyl ether, the fat content is calculated by evaporating the ethyl ether with a water bath (Anggorodi, 1984). The effect of using taro flour on the crude fat content 
of the pellets produced in this study is presented in Table 3.

The results of the analysis of variance showed that the forage treatment of different protein sources in this study had a very significant effect $(\mathrm{P}<0.01)$ on pellet crude fat. This difference in fat content is due to the different fat content of the raw materials for making pellets. The quality of feed ingredients and the manufacturing process can cause differences in different fat content (Zaenuri et al., 2014). Fat is one of the main sources of energy that rabbits need. Based on Duncan's multiple-distance test, fat in the treatment with Moringa was the lowest and significantly different $(\mathrm{P}<0.05)$ compared to other treatments, while the treatment without the use of forage, turi and lamtoro did not differ.

\section{Coarse Fiber}

Wahju (2015) stated that crude fiber consists of lignin, hemicellulose and cellulose, most of which cannot be digested by monogastric animals such as poultry and rabbits, and acts as a buffer or bulky. The results of the analysis of variance showed that pellets with the addition of forage protein sources had a significant effect $(\mathrm{P}<0.05)$ on the crude fiber content of rabbit pellets. Crude fiber in this study ranged from $12.20-14.80 \%$. This crude fiber is in the recommended range for rabbits, namely $12-14 \%$ crude fiber (McNitt et al., 2011). In the treatment without forage, the protein source had the lowest crude fiber content of $12.20 \%$ and was significantly different $(\mathrm{P}<0.05)$ with the treatment using forage. The use of Moringa forage was not significantly different $(\mathrm{P}>0.05)$ with the use of lamtoro but not different from turi. The treatment using turi forage in pellets was not significantly different $(\mathrm{P}>0.05)$ with lamtoro. This was due to differences in the fiber content of the feed ingredients, namely $6.98 \%$ soybean meal, $14.19 \%$ moringa, 15.33 turi and $25.11 \%$ lamtoro. Scientists et al., (2015) stated that the components of raw materials, especially the content of starch, protein, crude fiber, lignin and fat affect the physical quality of pellets.

\section{CONCLUSION}

The use of different forage protein sources in rabbit complete feed pellets does not affect the physical quality of rabbit pellets, so physically it has the same quality as feed without forage protein sources.

\section{REFERENCES}

Akbar, M., D. Suci, dan I. Wijayanti. 2017. Evaluasi kualitas pellet pakan itik yang disuplementasi tepung daun mengkudu (Morinda citrifolia) dan disimpan selama 6 minggu. Buletin Makanan Ternak, 104 (2), $31-48$.

Akhadiarto, S. 2010. Pengaruh pemanfaatan limbah kulit singkong dalam pembuatan pelet ransum unggas. Jurnal Teknik Lingkungan, 11 (1), 127-138.

Daryatmo, dan M. R. Hakim. 2017. Performa itik lokal (Anas sp) yang diberi tepung daun kelor (Moringa oleifera) pada pakan dengan sistem pemeliharaan intensif. JITRO, 4 (2), 33-39.

Dewanti, L.P., A. Widodo, dan E. Fadhilah. 2016. Pengaruh pemberian tepung daun kelor (Moringa oleifera) varietas Nusa Tenggara Timur terhadap kadar albumin Darah tikus putih (Rattus norvegicus strain wistar) yang diberi diet non protein. Jurnal Kesehatan, 1 (1), 23-39.

Dozier, W. A., K. C. Behnke, C. K. Gehring, and S. L. Branton,. 2010. Effects of feed form on growth performance and processing yields of broiler chickens during a 42-day production period 1. J. Appl. Poult Res., 19, 219-226. https://doi.org/10.3382/japr.2010-00156

Gasperz, V. 2006. Teknik analisa dalam penelitian percobaan (Edisi III). Bandung: Tarsito.

Gohl, B. 1981. Tropical Feeds. Rome: FAO of United Nations.

Jaelani, A., S. Dharmawati, dan Wacahyono. 2016. Pengaruh tumpukan dan lama masa simpan pakan pelet terhadap kualitas fisik. Ziraa'ah, 41 (2), 261-268.

Kastalani. 2015. Pengaruh Pemberian Rumput Lapangan (Paspalum conjugatum) dan Daun Lamtoro Gung (Leucaena leocochepala) Terhadap Bobot Karkas Kelinci Lokal Jantan (Orictolagus cuniculus). Jurnal Ilmu Hewan Tropika, $4(2), 32-34$.

Krisnan, R., dan S. P. Ginting,. 2009. Penggunaan solid ex-decanter sebagai perekat pembuatan pakan komplit 
berbentuk pelet: evaluasi fisik pakan komplit berbentuk pelet. In Seminar Nasional Teknologi Peternakan dan Veteriner (pp. 480-486).

Marhaeniyanto, E., S. Rusmiwari, dan S. Susanti. 2015. Pemanfaatan daun kelor untuk meningkatkan produksi ternak kelinci New Zealand White. Buana Sains, 15 (2), 119-126.

McNitt, J. I., N. M. Patton, P. R. Cheeke, and S. D. Lukefahrl. 2011. Rabbit Production $\left(8^{\text {th }}\right.$ ed.). Oxfordshire UK: CAB International.

Nurhayatin, T., and M. Puspitasari. 2017. The effect of processing method of arrowroot tuber (Maranta arundinacea) as binder and length of storage time on physical quality pellet feed for chicken broiler. JANHUS Journal of Animal Husbandry Science, 2 (1), 32-40.

Retnani, Y., E. D. Putra, dan L. Herawati,. 2011. Pengaruh Taraf Penyemprotan Air dan Lama Penyimpanan Terhadap Daya Tahan Ransum Broiler Finisher Berbentuk Pellet. Agripet, 11(1), 10-14.
Retnani, Y., R. S. Rachman, dan H.A. Sukria. 2010. Pengaruh Pengurangan Jagung Sebagai Sumber Pati terhadap Laju Alir Pellet Pada Proses Produksi Berkesinambungan. Agripet, 10 (2), 16-20.

Sjofjan, O. 2008. Efek penggunaan tepung daun kelor (Moringa oleifera) dalam pakan terhadap penampilan produksi ayam pedaging. In Seminar Nasional Teknologi Peternakan dan Veteriner 2008 (pp. 649656).

Utami, I. K., K. Haetami, dan Rosidah. 2012. Pengaruh penggunaan tepung daun turi hasil fermentasi dalam pakan buatan terhadap pertumbuhan benih bawal air tawar (Colossomamacropomum cuvier). Jurnal Perikanan Dan Kelautan, 3(4), 191199.

Yurmiaty, H., dan K. Suradi. 2007. Penggunaan Daun Lamtoro (Leucaena leucocephala) dalam Ransum terhadap Produksi Pelt dan Kerontokan Bulu Kelinci. Jurnal Ilmu Ternak, 7(1), 73-77. 